\title{
HEALTH AND SAFETY IN INDUSTRY
}

$\mathrm{T}$ HE annual report of the Chief Inspector of Factories for 1938 gives an encouraging picture of the way in which health and safety in industry in Great Britain are being improved. Although the report deals only with the first six months during which the Factory Act of $193 \bar{i}$ was in force, it indicates that great progress has been made in applying the new code and raising the standard of all factories and workshops to the level of the best. Indeed, a striking feature of the coming into operation of the Act, the report points out, has been the co-operation of employers, whose inquiries have been directed to the best manner of doing this or that, rather than to the necessity of doing it. Accordingly, the factory inspector is now regarded more as an expert adviser on problems of health and safety and less as an official with punitive powers.

In regard to safety, the new Act marked an extension of safety regulations to diminish accidents. The report shows that in 1938 the number of reportable accidents was 7 per cent less than in 1937, while fatal accidents were reduced by 6 per cent. While, however, these figures remain at the high level of 180,103 and 944 respectively, there is still plenty of room for improvement in this respect, and the fall in accidents must be attributed to some extent to the reduction of the number of people in employment in consequence of the trade depression. In this connexion, the chief inspector pointed out that the decrease was especially marked among the fatal accidents on factory premises, and considered that the new safety requirements are already beginning to take effect. It should, of course, bo remembered that the relative value of the accident figures for 1938 is affected by the wider requirements in the new Act for reporting accidents.

An important factor in the prevention of accidents is the work of the Safety Committees and safety officers throughout the country, particularly in the larger factories. In such work, scientific workers have an important part to play. Success in this matter depends largely on their technical knowledge and interest, and their skill in enlisting the cooperation of fellow-workers who may not possess such expert knowledge. Moreover, siznificantly enough, the report points out, special difficulty is often experienced in small factories, for example, in the elimination of fire risk through effective protection of circuits from persistent earth leakage, because neither the instruments required nor the ability to use them are available.

If, therefore, the report contains welcome evidence that the management side is increasingly alive to its responsibilities in this matter, it once more endorses the far-sightedness of the policy of such professional associations as the British Association of Chemists in attempting to secure that certain specified operations are carried out under the direct supervision of properly qualified persons. This is indeed essential in the development of new processes, and the value of such a safeguard tends to increase as the pressure due to national defence requirements increases. From the point of view of safety, no less than health, the reduction of hours of work is a wise and beneficial measure.

Once again an important section of the report is concerned with accidents to young workers. A most serious problem in factories to-day is indeed to protect young workers from the alarming proportion of accidents occuring in the ago group 14-18, which are often due to carelessless, ignorance or lack of discipline. The education authorities are now endeavouring to prepare boys and girls for the risks of their future employment by giving such training as they can to the young people while they are still attending colleges or schools. Progress in this matter obviously depends on closo co-operation with employers themselves. The report points out that the firms which are most successful in reducing accidents to young workers are those which regard their employees both from the personal point of view and that of their future value as skilled workers. Moreover, if the number of accidents is to be reduced as far as possible, the training and supervision of the young entrants into industry must be extended beyond their instruction with regard to the use of machinery, for most of the injuries due to accidents come from other causes.

At the present time there is a further factor in the shortage of young workers, which may tend to increase this already alarming incidence of accidents among young workers. Duo to this shortage there may be greater danger that boys and girls may be placed in positions for which they are not most suitable. If it is a counsel of perfection at the present time to select boys and girls who are the most suitable mentally and physically for the work which has to be done, at least greater care could be taken to prevent those specially prone to accidents from being placed in the more hazardous posts. Moreover, the fact that accidents tend to occur to particular boys and girls whom the management consider to be among the smartest and most intelligent in the works is a further demonstration of the need of close guidance and supervision if only to maintain discipline, to remedy lack of experience, for example, as to the type of clothing worn, and prevent dangerous experiments on the part of young workers due to their inquisitiveness and eagerness to try out ideas of their own.

While, therefore, the evidence presented in this report shows that the great developments in organized attempts to reduce accidents in recent years are gradually achieving their object, there can be no reasonable room for doubt that great efforts still continue to be required in this field, and notably in attention to the young workers. The field of research open to the Industrial Fealth Research Board remains a wide one, and it is significant that special attention is directed to this matter in the programme recently formulated by the Scientific Advisory Com. mittee of the Trades Union Congress. At its first meeting this committeo agreed that tho subjects upon which the committee might be consulted in regard to their effect on labour and social conditions should include the position of research in relation to 
industrial and occupational diseases with a view to prevention rather than cure, and also researches into industrial fatigue and nerve strain, including systems of labour measurement in relation to shorter working hours, holidays and minimum periods for rest and recreation. 'Two sub-committees have been formed to give their attention to these subjects and a third sub-committee to deal with the effects of new industries, new materials, new uses of new processes, upon the distribution, displacement and character of labour with particular reference to plastics, textiles and non-textile products.

In view of the increasing responsibilities which scientific workers must assume for control and management in industry, the report of the Chief Inspector of Factories is a timely reminder to them of their opportunities and responsibilities in this important field.

\section{FISHERY RESEARCH IN SCOTLAND}

$\mathrm{T}$ $\mathrm{HE}$ passing of the Fishery Board for Scotland, under the Reorganisation of Offices (Scotland) Act, means the removal of a landmark from the field of fishery research. As the Development Commissioners observe in their latest annual report, the Board was the first department of Government in the United Kingdom to possess a permanent scientific organization, and its scientific staff was responsible for many of the earlier classical discoveries in marine research, while in more recent years it has made important contributions to the development of fishery science.

Since its inception, the Board has had its head. quarters in Edinburgh, one of the homes of the modern science of oceanography. From Edinburgh, Edward Forbes conducted much of his pioneer work of shallow-water dredging and Dr. Bruce his polar researches, and the city is for over to be associated with the famous Challenger expedition and the names of those deep-sea explorers, Sir Wyville Thomson and Sir John Mrurray. The last-named was scientific member of the Fishery Board and the chief British delegate at the International Congress held at Stockholm in 1899 - a congress which led to the formation of the International Council for the Exploration of tho Sea.

It would probably amaze some of these pioneer fishery investigators to see how far governmental interest in research, land and marine, has progressed since their time. There are many to-day who, like Forbes, would prefer to see scientific research conducted without the trammels of officialdom; but finance is a hard taskmaster and has a way of assuming the direction and control of policy. Certainly, without Government funds the conduct of marine research would, in view of the costly equipment and staff required, be a difficult undertaking for private enterprise.

It was in 1882 , following a report by a Select Committee of the House of Commons, which was impressed by the progress of fishery research in the United States, that the Fishery Board for Scotland was empowered to carry on scientific researches. The funds provided were on a modest scale, but the Board was enabled in 1886 to acquire a small steam research vessel, the Garland, which was employed mainly in investigating the effects of trawling on the inshore fisheries. With the great development of trawling, this question had become one of much public and political interest, especially in Scotland, where the inshore fisheries are of considerable importance. The investigations are described in Prof. WV. C. IrcIntosh's "Resources of the Sea", in which the author did not support the Board in the policy of restriction of trawling on which it decided.

In 1895 the Board was reconstituted, and " $a$ person of skill in the branches of science concerned with the habits and food of fishes" was thenceforward included as one of its members. 'The role was filled in turn by such distinguished men of science as Prof. Cossar Ewart, Prof. W. C. McIntosh and Sir John Murray, and since 1898 the scientific member of the Board has been Sir D'Arcy IV. Thompson, who has taken so long and honourable a part not only in fishery science but also in many other fields of culture and education.

The establishment in 1902 of the International Council for the Exploration of the Sea gave a great fillip to marine research, and the share of the pro. gramme of international research assigned to Great Britain was entrusted, so far as the northern half of the North Sea was concerned, to the Fishery Board for Scotland acting as agent for the Treasury. The work in the southern half of the North Sea was undertaken originally by the Marine Biological Association and afterwards, in 1910, by the Board (now Ministry) of Agriculture and Fisheries.

A new research vessel, the Goldseeker, was provided for the Fishery Board in 1902, and she was replaced in 1920, by means of a grant from the Development Fund, by tho research vessel Explorer, which is still in commission.

I aboratories were set up at Dunbar, Granton and Tarbert (Loch Fyne) and finally at Aberdeen, where the Board's scientific staff is now stationed. The Board has been fortunate in securing the services of a succession of scientific superintendents of outstanding ability, of whom Fulton and Bowman may bo specially mentioned. Apart from his varied contributions to fishery science, Fulton found time to write the "Sovereignty of the Sea", a valuable historical survey of questions of maritime jurisdiction, while Bowman laid the foundation for the forecasts which have now become possible of the stocks of haddock in the sea.

The statistical records of the Board are of the greatest value. Sir D'Arcy Thompson is personally responsible for $れ$ series of statistical reports on the fisheries of the North Sea, which are indispensable to any proper study and appreciation of fishery problems.

In conclusion, it is fitting to mention the contributions made by the Board to salmon and freshwater fishery research. The names of Archer, Young, Calderrood and Menzies, in turn inspectors of salmon fisheries, stand high as authorities in this branch of science.

H. J. C. 